\title{
PLCG1 Gene
}

National Cancer Institute

\section{Source}

National Cancer Institute. PLCG1 Gene. NCI Thesaurus. Code C104821.

This gene is involved in both intracellular signaling and second messenger production. 